\title{
Sobre o prazer que há na vertigem, o mundo lá fora e fins que doem na mesma medida em que são absolutamente inevitáveis
}

\section{Emanuela Gava Caciatori'}

Eu não tinha ideia de qual seria o buraco que ficaria no meu peito quando eu finalmente levantasse da mesa ao me dar conta de que o amor não estava sendo servido, e que nem seria. Mas, de qualquer forma, foi maior do que eu imaginei. Eu não sei precisar em que momento eu simplesmente soltei as mãos do volante e decidi ignorar todas as possíveis e prováveis más consequências e aceitei me jogar na incerteza cuja única certeza era a possibilidade iminente de uma catástrofe: como se eu tivesse dirigindo sem as mãos no volante e com os olhos vendados. Mas nesse interregno de tempo, entre o início incerto e o fim inevitável, eu (nós) decidi(mos) sentir a adrenalina. $O$ problema é que você estava no banco do passageiro, com o cinto de segurança, um capacete e o seu air bag estava funcionando. Já eu, estava à minha própria sorte, completamente desnuda, pedindo por favor praquilo durar só um tantinho mais, pra eu desfrutar um momento outro e poder fingir por mais um instante que seria possível ignorar tudo que existia e era real do lado de fora dessa viagem num

1 Mestranda em Direitos Humanos na Universidad Autónoma de San Luis Potosí (UASLP/ México). Bolsista CONACYT (México). Graduada em Direito na Universidade do Extremo Sul Catarinense (UNESC/Brasil). Pesquisadora CLACSO no GT Crítica Jurídica y Conflictos Sociopolíticos (2019-2022). Pesquisadora do Grupo Pensamento Jurídico Crítico Latino-americano, na linha de Constitucionalismo Crítico (UNESC/Brasil). Colaboradora voluntaria na Defensoria Pública da União (Brasil). 
carro louco \& desgovernado. Sempre que a gente se encontrava o mundo lá fora parecia não existir, ou simplesmente não importava o que estivesse para além das paredes que confidenciavam nosso romance. Eram algumas horas de falsa segurança, como se fosse capaz de existir aconchego e proteção ao ancorar meu barco num porto comandado por piratas. Mas eu gostava da sensação, uma espécie de vertigem estranhamente boa, e então eu silenciava os pensamentos razoáveis pra seguir saboreando e me segurando a essa sensação. Como se fosse possível se firmar e construir alicerces firmes em um chão de areia fofa. Como se o tempo fosse se permitir correr de maneira diferente só pra ser benevolente com a gente e os nossos desejos, meio egoístas, meio bobos, meio infantis, mas sempre sempre puros. A gente estava parado, de frente, encarando coisas que não queria enfrentar, porque sabia que ia doer, só que essas coisas foram aumentando e crescendo cada vez mais, não importando o quão forte a gente quisesse ignorar aquele elefante na sala, que no início tinha o tamanho de um objeto de decoração, no máximo. A gente decidiu não decidindo e o elefante foi crescendo até ficar gigante e nos obrigar a sair da sala, porque ali já não havia espaço pra mais nada além daquele estupido elefante gigantesco, que já não dava mais pra ignorar. Foi como uma ferida que a gente coloca um curativo pra sarar e que eventualmente é necessário tirar o esparadrapo, pra deixar o machucado respirar e poder curar. Só que em vez de puxar o curativo rápido pra doer menos, a gente foi remendando-o, e a cola velha se misturava com a nova e com a pele e quando mais fundo se ia mais se sabia que ia doer e menos se queria encarar o inevitável. Eu senti -e sei que você também- que o nosso último beijo seria o último: tinha gosto de despedida. Foi agridoce e bizarramente reconfortante. $\mathrm{O}$ abraço demorado também, assim como a falsidade sutil na despedida dita que consistiu em algo como até-a-próxima-a-gente-se-vê quando eu desci do seu carro, que sabíamos que era uma (outra) promessa falsa, mas que mais uma vez necessitávamos dessa dissimulada sensação de reconforto. Aceitamos e encaramos o fim sem aceitar e encarar o fim, porque essa é a forma covarde de aceitar e encarar fins que doem e dilaceram, mas que também são inevitáveis, quiçá 
na mesma medida. Há, contudo, certa coragem na covardia, penso eu. $E$ ninguém pode negar -ainda que ninguém saiba, porque esse sempre foi nosso grande e sujo segredo- que com você eu fui mais valente do que nunca.

Criciúma/SC, verão, últimos dias de 2019.

Faz calor e o tempo é úmido. 